Tropical Journal of Pharmaceutical Research October 2016; 15 (10): 2063-2070

ISSN: $1596-5996$ (print); 1596-9827 (electronic)

(C) Pharmacotherapy Group, Faculty of Pharmacy, University of Benin, Benin City, 300001 Nigeria.

All rights reserved.

Available online at http://www.tjpr.org

Original Research Article

http://dx.doi.org/10.4314/tjpr.v15i10.2

\title{
a-Mangostin suppresses 12-o-tetradecanoylphorbol-13- acetate-mediated matrix metalloproteinase-9 expression in human osteosarcoma cells U2OS
}

\author{
Ruchadaporn Kaomongkolgit ${ }^{1 *}$ and Ichaya Yiemwattana ${ }^{2}$ \\ ${ }^{1}$ Department of Oral Diagnosis, ${ }^{2}$ Department of Preventive Dentistry, Faculty of Dentistry, Naresuan University, Phitsanulok, \\ Thailand
}

*For correspondence: Email: ruchadapornk@nu.ac.th; Tel: +665 966065; Fax: +665 966053

Received: 19 June 2016

Revised accepted: 18 September 2016

\begin{abstract}
Purpose: To investigate the effect of $\alpha$-mangostin on matrix metalloproteinase (MMP)-2 and MMP-9 expression in U2OS human osteosarcoma cell lines.

Methods: Cytotoxicity of $\alpha$-mangostin on U2OS cells was determined by MTT assay. MMP-2 and MMP9 activities, and mRNA expression of a-mangostin-treated U2OS cells were evaluated using gelatin zymography and real-time polymerase chain reaction (PCR), respectively. Wound healing assay was used to determine whether $\alpha$-mangostin inhibits 12-O-tetradecanoylphorbol-13-acetate (TPA)-induced migration of U2OS cells.

Results: U2OS viability was significantly decreased when cells were exposed to $\alpha$-mangostin at 2.5 and $5 \mu \mathrm{g} / \mathrm{mL}$ compared to the untreated control $(p<0.05)$. a-Mangostin inhibited MMP-2 and MMP-9 activities stimulated by TPA at concentrations of 1.0, 1.5, and $2.0 \mu \mathrm{g} / \mathrm{mL}$. MMP-9 mRNA expression of TPA treated U2OS was down-regulated by a-mangostin. However, MMP-2 mRNA levels remained unchanged. Would healing assay revealed that $\alpha$-mangostin $(2 \mu \mathrm{g} / \mathrm{mL})$ significantly inhibited TPAinduced U2OS migration compared to the control $(p<0.05)$.

Conclusion: This is the first study reporting the inhibitory effects of a-mangostin on TPA-mediated MMP-9 expression and TPA-induced migration of U2OS cells. Thus, it is a potential therapeutic agent for the treatment of osteosarcoma.
\end{abstract}

Keywords: a-Mangostin, Matrix metalloproteinase, Osteosarcoma, Cell migration, 12-0Tetradecanoylphorbol-13-acetate, Wound healing, Zymography

Tropical Journal of Pharmaceutical Research is indexed by Science Citation Index (SciSearch), Scopus, International Pharmaceutical Abstract, Chemical Abstracts, Embase, Index Copernicus, EBSCO, African Index Medicus, JournalSeek, Journal Citation Reports/Science Edition, Directory of Open Access Journals (DOAJ), African Journal Online, Bioline International, Open-J-Gate and Pharmacy Abstracts

\section{INTRODUCTION}

Osteosarcoma is the most common primary bone malignancy found in children and young adults. It usually occurs in the distal long bones, but can also affect other bones in the body [1]. Chemotherapy is one of the most essential treatments for osteosarcoma. Although a number of chemotherapeutic agents have been used to treat osteosarcoma, survival rate of patients has not been substantially improved [2]. One of the primary reasons for the failure of current treatments is that patients with stage IV cancer often develop resistance to anticancer agents [3]. Matrix metalloproteinases (MMPs) are a major group of enzymes that regulate cell-matrix composition. Gelatinases (MMP-2 and MMP-9) are members of MMP family that plays an important role in the progression and metastasis of human cancers [4]. Previous reports have showed that MMP-2 and MMP-9 were identified in osteosarcoma tissue and can participate in the 
progression of osteosarcoma [5]. In addition, a recent study demonstrated that MMP-2 overexpression was related to a poor prognosis [6] and high MMP-9 expression were significantly associated with lower overall survival compared to their counterparts with low or undetectable MMP-9 expression [7].

a-Mangostin is a plant-derived antitumor xanthone isolated from Garcinia mangostana Linn. or mangosteen. This agent possesses a variety of pharmacological activities including anticancer, cytotoxicity, antioxidant, antiinflammation, antihistamine, antibacterial activity, antifungal activity, anti-HIV, antiulcer, and CNS depressant activities [8]. In vitro and in vivo studies demonstrated that $\alpha$-mangostin displayed a broad antitumor activity against various human cancer cells [9]. In addition, a-mangostin was able to induce apoptotic cell death in canine osteosarcoma D-17 cells [10] and inhibited metastasis of human cancer cells [11-16]. However, there was no data about the effect of a-mangostin on the MMP expression in human osteosarcoma cells.

The purpose of this study was to investigate the effect of $\alpha$-mangostin on MMP-2 and MMP-9 expression in U2OS human osteosarcoma cell lines in vitro.

\section{EXPERIMENTAL}

\section{Preparation of $\alpha$-mangostin}

a-Mangostin was received from Department of Pharmacognosy and Pharmaceutical Botany, Faculty of Pharmaceutical Sciences, Chulalongkorn University, Thailand. The purified a-mangostin was prepared according to the protocol of a previous study [17]. The pericarp of mangosteen was macerated in hexane to remove nonpolar compounds and was subsequently macerated in ethyl acetate. $\alpha$ Mangostin was obtained from the crude extract by chromatography on a silica gel column and elution with hexane/ethyl acetate (4:1). The selected fraction was identified as $\alpha$-mangostin using mass spectrometry, nuclear magnetic resonance spectroscopy, and a Gallenkamp melting-point apparatus.

\section{Cell culture}

Human osteosarcoma cell line (U2OS) was kindly provided by Professor Dr. Prasit Pavasant (Faculty of Dentistry, Chulalongkorn University). Cells were cultured in Dulbecco's modified Eagle's medium supplemented with $10 \%$ fetal bovine serum (FBS), $2 \mathrm{mM}$ L-glutamine, 100 $\mathrm{IU} / \mathrm{mL}$ penicillin, $100 \mu \mathrm{g} / \mathrm{mL}$ streptomycin and 5 $\mu \mathrm{g} / \mathrm{mL}$ amphotericin $\mathrm{B}$ at $37^{\circ} \mathrm{C}$ in humidified atmosphere of $95 \%$ air, $5 \% \mathrm{CO}_{2}$. Medium and supplements were purchased from Gibco® (Grand Island, NY, USA).

\section{MTT assay}

Cytotoxic effect of a-mangostin and 12-Otetradecanoylphorbol-13-acetate (TPA) (Sigma ${ }^{\circledR}$, St. Louis, MO, USA) on U2OS cells were determined by 3-(4,5-dimethylthiazol-2-yl)-2,5diphenyl-tetrazolium bromide (MTT) test (Sigma®, St. Louis, MO, USA). MTT assay is based on the reduction of the yellow tetrazolium salts to purple formazan crystals by dehydrogenase enzymes secreted from the mitochondria of metabolically active cells. The amount of purple formazan crystal is proportional to the number of viable cells. MTT assay was performed according to the manufacturer's instruction. Cells were seeded at $5 \times 10^{4}$ cells per well in 24-well plate. The cells were serumstarved and then treated with various doses of $\alpha$ mangostin $(0,0.5,1.0,1.5,2.0,2.5$ and $5 \mu \mathrm{g} / \mathrm{mL})$ in serum free culture medium as previously mentioned. After 24 or $48 \mathrm{~h}$, the culture medium was aspirated, replaced with $0.5 \mathrm{mg} / \mathrm{mL}$ MTT solution and incubated for $30 \mathrm{~min}$ at $37^{\circ} \mathrm{C}$ in a 5 $\% \mathrm{CO}_{2}$ humidified atmosphere. The solution was then aspirated and $1000 \mu \mathrm{L}$ of DMSO (Sigma ${ }^{\circledR}$, St. Louis, MO, USA) was added to dissolve the formazan crystals. The absorbance was measured at $570 \mathrm{~nm}$ using Genesis10 UV-vis spectrophotometer (Thermo Spectronic, NY, USA). Viable cell number was calculated from the standard curve of cell number [15].

\section{Gelatin zymography}

Gelatin zymography was used to determine MMP-2 and MMP-9 activities secreted from U2OS cells. Briefly, conditioned media were collected and resolved in $10 \%$ sodium dodecyl sulfate polyacrylamine gel electrophoresis (SDSPAGE) gels copolymerized with $1 \%$ gelatin. Then, Gels were washed three times with $2.5 \%$ Triton X-100 and incubated in buffer containing $50 \mathrm{mM}$ Tris, $10 \mathrm{mM} \mathrm{CaCl}, 0.15 \mathrm{M} \mathrm{NaCl}$, and $0.02 \%$ Briji-35 at $37{ }^{\circ} \mathrm{C}$ overnight. Finally, Gels were stained with $0.1 \%$ Coomassie Brilliant Blue R250 in $7.5 \%$ acetic acid and $12.5 \%$ methanol for $30 \mathrm{~min}$, and then destained in $7.5 \%$ acetic acid and $5 \%$ methanol to visualize the proteolytic bands. Bands were quantified using Scion Image software (Scion Corporation, Frederick, MD, USA) [15]. 


\author{
Real-time polymerase chain reaction (RT- \\ PCR)
}

Total RNA was isolated by Nucleospin RNAIl (Macherey-Nagel $\mathrm{GmbH} \& \mathrm{Co}$. KG) following the product protocol. The mRNA concentrations of the samples were determined using the Nanodrop (ND-2000c; Thermo Fisher Scientific, Wilmington, USA). cDNA was synthesized from 1

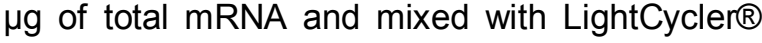
480 DNA SYBR Green I Master (Roche Diagnostics $\mathrm{GmbH}$, Mannheim, Germany) and gene-specific primers (Takara Bio, Shiga, Japan) according to the manufacturer's instructions. The PCR primer sequences of the MMP-2, MMP-9, and GAPDH were used as follows: sense primer for MMP-2, 5'-GGCCCT GTCACTCCTGAGAT-3' and anti-sense 5'-GGCATCCAGGTTATCGGG GA-3'; sense primer for MMP-9, 5'-GACTCGG TCTTTGAGGAGCC-3' and antisense 5'-GAAC TCACGCGCCAGTAGAA-3', and sense primer for GAPDH, 5'-TGAAGGTCGGAGTCAACGG AT-3' and antisense 5'-TCACACCCAT GACGAACATGG-3'. All PCR reactions were performed in duplicate using the LightCycler $®$ 480 II Real-Time PCR System (Roche Diagnostics Ltd, Rotkreuz, Switzerland).

The cycling conditions were as follows: initial denaturation at $95{ }^{\circ} \mathrm{C}$ for $3 \mathrm{~min}$, followed by 40 cycles at $95{ }^{\circ} \mathrm{C}$ for $10 \mathrm{~s}, 53{ }^{\circ} \mathrm{C}$ for $45 \mathrm{~s}$. A melt curve assay was then performed $\left(55^{\circ} \mathrm{C}\right.$ for $1 \mathrm{~min}$ and then the temperature was increased by 0.5 ${ }^{\circ} \mathrm{C}$ every $10 \mathrm{~s}$ ) to detect the formation of primerderived trimers and dimers. To ensure the fidelity of mRNA extraction and reverse transcription, all samples were subjected to PCR amplification with oligonucleotide primers specific for the constitutively expressed gene glyceraldehyde-3phosphate dehydrogenase (GAPDH) and normalized. Data were analyzed with the LightCycler® 480 software version 1.5 . Quantification was calculated using the starting quantity of the cDNA of interest relative to that of GAPDH cDNA in the same sample [18].

\section{Wound healing assay}

To determine cell motility, U2OS cells were seeded as previously described and grown until they were completely confluent. Cells were wounded by scratching with a sterile yellow micropipette tip and washed with PBS three times. Cells in each well were then incubated with TPA $(10 \mathrm{nM})$ with or without the different concentrations of a-mangostin for $24 \mathrm{~h}$. Photographs were taken (Olympus DP72, Hamburg, Germany) before and after $24 \mathrm{~h}$ of treatment and cell migration was measured using
Imaging software (CellSens, Olympus, Hamburg, Germany) [19].

\section{Statistical analysis}

All data are expressed as the mean \pm standard deviation ( $S D, n=3$ ). The results were analyzed using Student's t-test, and differences were considered statistically significant only if $p<0.05$. All statistical analyses were performed by SPSS for Windows software (version 13.0; SPSS Inc, Chicago, IL, USA).

\section{RESULTS}

\section{Cell viability of U2OS cells treated with $\alpha-$ mangostin}

Cytotoxicity of a-mangostin was first determined by treating U2OS cells with various concentrations of $\alpha$-mangostin $(0,0.5,1.0,1.5$, 2.0, 2.5 and $5 \mu \mathrm{g} / \mathrm{mL}$ ) for 24 and $48 \mathrm{~h}$ followed by MTT assay. As shown in Fig. 1, a-mangostin inhibited growth of U2OS cells in a concentration dependent manner. a-Mangostin at concentrations between 0 and $2.0 \mu \mathrm{g} / \mathrm{ml}$ was not toxic as the cell viability was not significantly altered compared to the non-treated control. However, at the concentration of 2.5 to $5 \mu \mathrm{g} / \mathrm{mL}$, cell viability was significantly decreased indicating the cytotoxicity at these concentrations. As a result, $\alpha$-mangostin at the concentrations $\leq 2.0 \mu \mathrm{g} / \mathrm{mL}$ were applied on all subsequent experiments.

\section{Inhibition of the TPA-induced expressions of MMP-9 by $\alpha$-mangostin}

Gelatin zymograhy showed proteolytic bands of MMP-2 and MMP-9 (Fig 2). Compared to the non-TPA treated cells, TPA significantly increased the MMP-9 activity. However, this effect was not observed for MMP-2. a-Mangostin significantly inhibited MMP-2 and MMP-9 activities stimulated by TPA at concentrations of 1.0, 1.5, and $2.0 \mu \mathrm{g} / \mathrm{mL}$. (Fig 2).

To determine whether the inhibitory effect of $\alpha$ mangostin on TPA-induced MMP activity was regulated at the transcription level, real-time PCR was used. As shown in Fig. 3, MMP-9 mRNA expression of TPA treated U2OS was downregulated by $\alpha$-mangostin at all concentrations used. However, MMP-2 mRNA levels remained unchanged. 
a-Mangostin inhibits TPA-induced migration of U2OS cells

As shown in Fig. 4, cell motility of TPA-induced U2OS cells was significantly increased, compared to untreated cells. Treatment U2OS cells with $0.5,1.0,1.5 \mu \mathrm{g} / \mathrm{mL}$ a-mangostin reduced the motility of cells induced by TPA, while $2 \mu \mathrm{g} / \mathrm{mL}$ a-mangostin significantly inhibited cell motility compared to the TPA-treated U2OS.

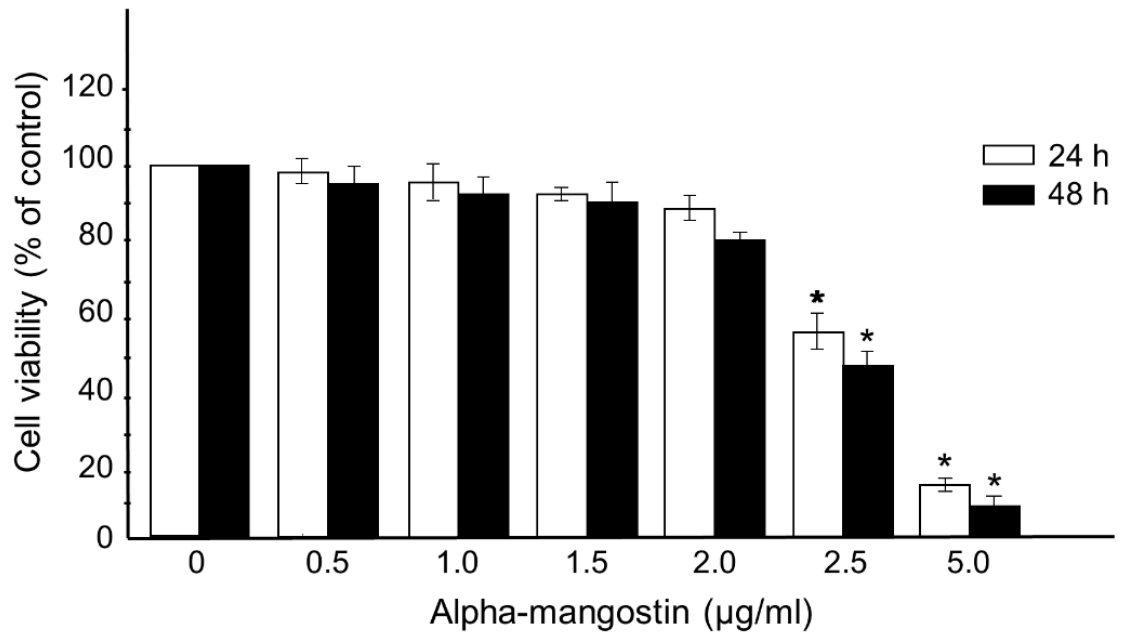

Figure 1: U2OS cell viability (\%) in response to the different concentrations of $\alpha$-magonistin measured by MTT assay at 24 and $48 \mathrm{~h}$ after exposure. a-Mangostin inhibited proliferation of U2OS cells in a concentrationdependent manner. The data (mean \pm SD) are the average of three independent experiments performed in triplicate; * indicates significant difference from the control $(p<0.05)$.

A

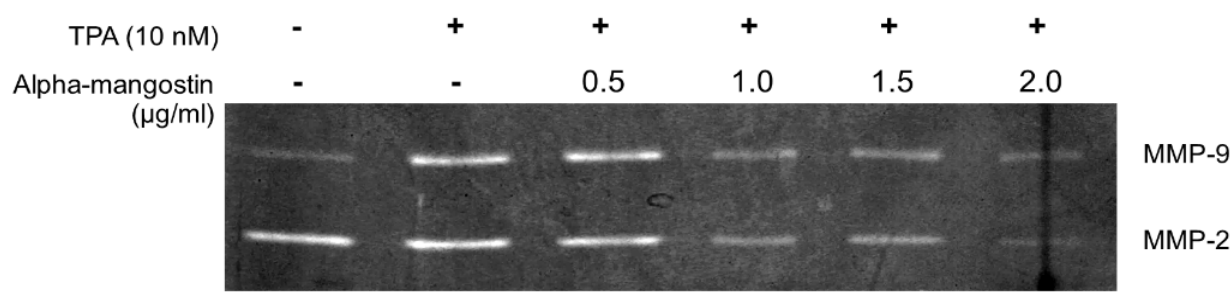

B

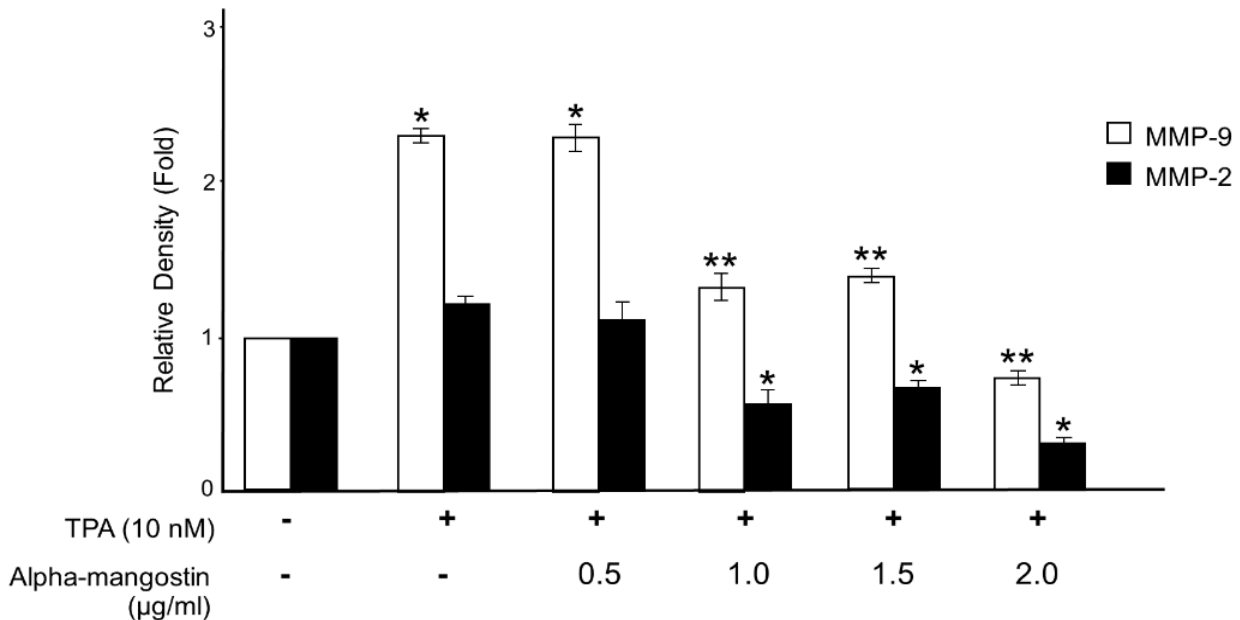

Figure 2: (A) Gelatin zymography of conditioned media treated with nontoxic concentrations of $\alpha$-mangostin for $24 \mathrm{~h}$. (B) Quantitative analysis (average \pm SD) of MMP-2 and MMP-9 activities. a-Mangostin suppressed MMP-2 and MMP-9 activities in U2OS cells. Cells were treated with non-toxic concentrations $(0.5,1.0,1.5$ and $2 \mu \mathrm{g} / \mathrm{mL})$ of a-mangostin for $24 \mathrm{~h}$. Conditioned media were subjected to gelatin zymography. Amount of protein loading was normalized to the cell number determined by MTT. Three independent experiments performed in triplicate; * indicates significant difference from the control $(p<0.05)$; ** indicates significant difference from TPA treatment only $(p<0.05)$ 


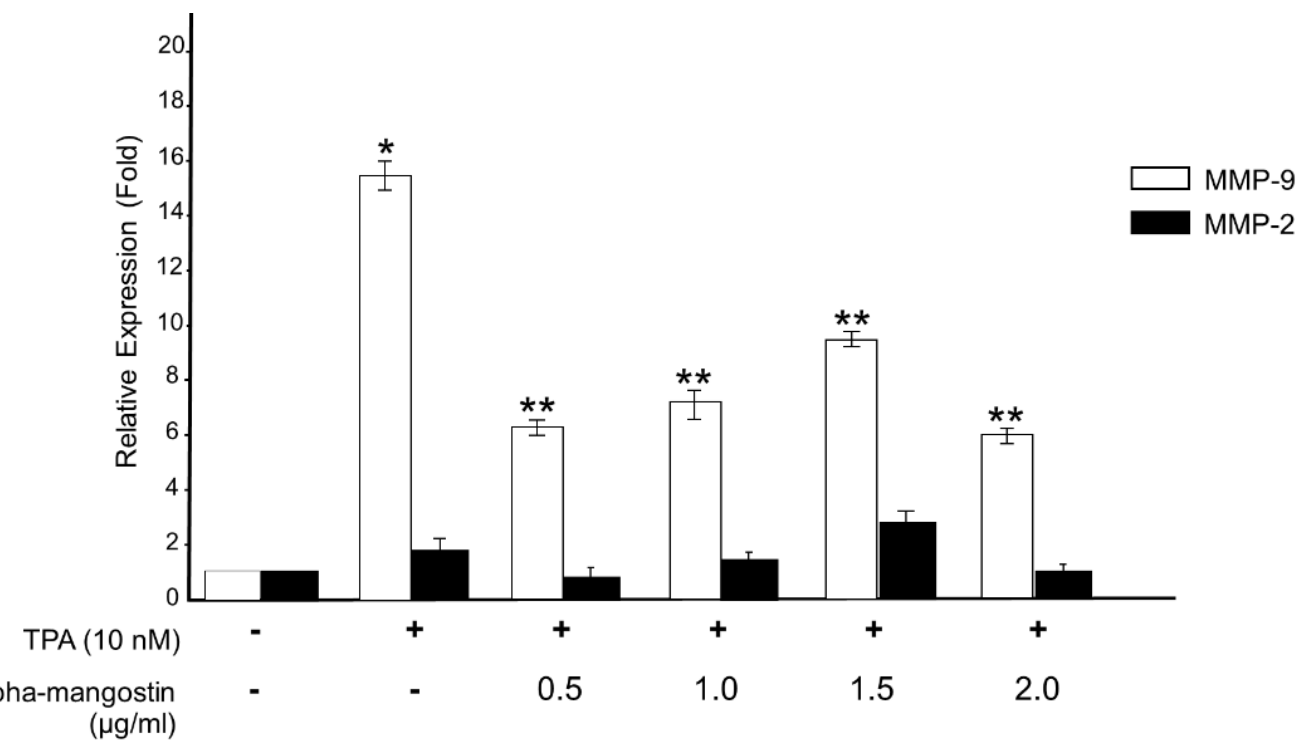

Figure 3: MMP-2 and MMP-9 mRNA expression (average \pm SD) of U2OS cells treated with nontoxic concentrations of $\alpha$-mangostin for 24 h. a-Mangostin suppressed MMP-9 expression in U2OS cells. Cells were treated with non-toxic concentrations of $\alpha$-mangostin for $24 \mathrm{~h}$ and mRNA were isolated for PCR. mRNA levels were normalized by GAPDH. Three independent experiments performed in triplicate; $*$ indicates significant difference from the control $(p<0.05) ; * *$ indicates significant difference from TPA treatment only $(p<0.05)$

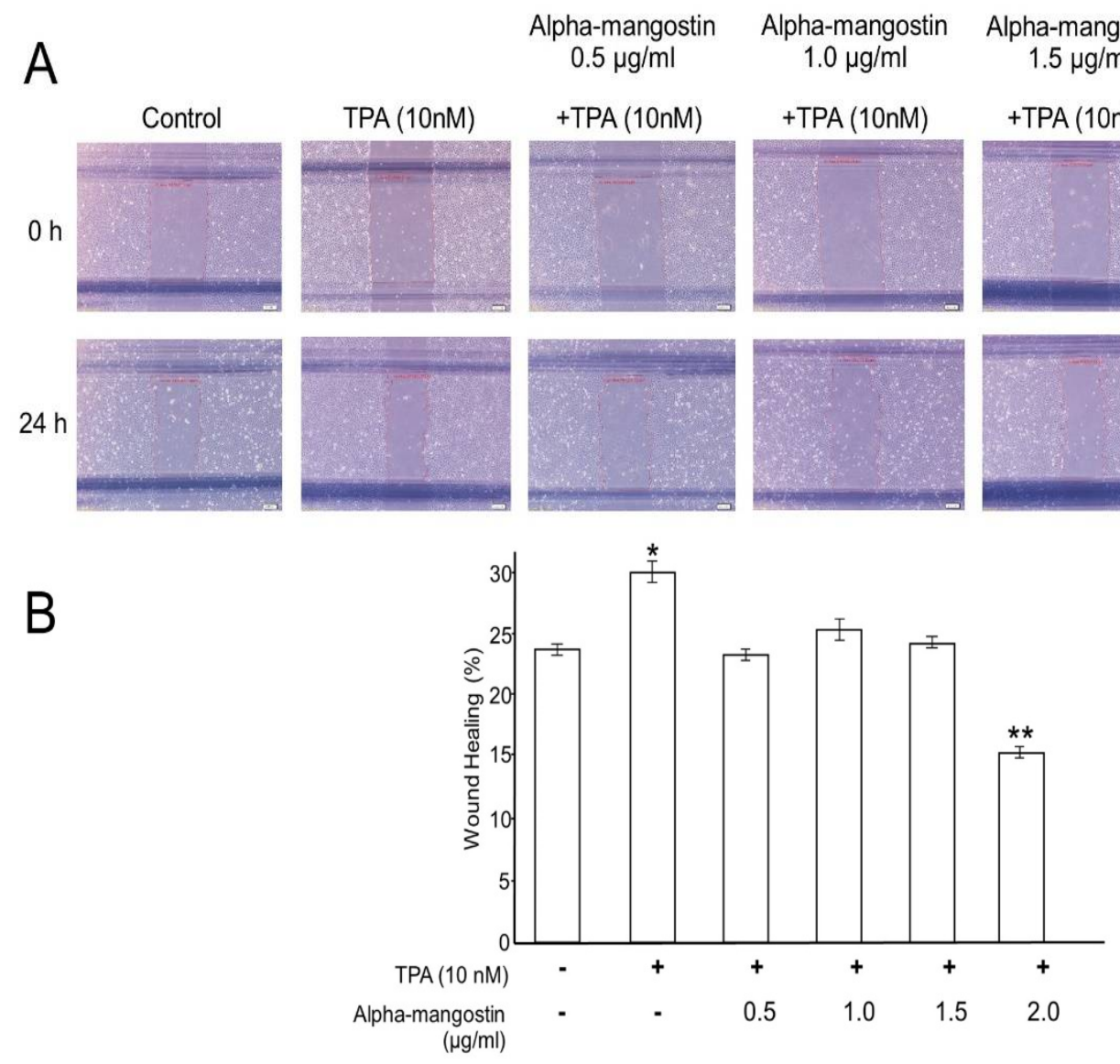

Figure 4: (A) Representative micrographs of the wound healing assay after TPA-treated U2OS cells were exposed with different concentrations of a-mangostin for $24 \mathrm{~h}$. (B) Quantitative analysis (average \pm SD) of the U2OS cell migration in response to a-mangostin. Inhibitory effect of a-mangostin on TPA-induced cell migration of U2OS cells was observed. Three independent experiments performed in triplicate; $*$ indicates significant difference from the control $(p<0.05) ; * *$ indicates significant difference from TPA treatment only $(p<0.05)$ 


\section{DISCUSSION}

Despite recent advances in osteosarcoma treatment, the disease still remains a leading cause of death among cancer patients [20,21]. In addition, osteosarcoma is a highly metastatic tumor [22]. Thus, an agent that could inhibit the development of metastasis would be beneficial to patients by improving their disease-free survival time. One of important characteristics of metastasis is the migratory ability of tumor cells. Several MMPs, including MMP-2 and MMP-9 are involved in tumor migration, and increase in MMP-2 and MMP-9 protein levels and enzyme activities were observed in clinically invasive cancers [23]. Previous reports indicated that MMP-2 and MMP-9 were found in osteosarcoma tissue and they could be involved in the osteosarcoma progression $[3,5]$.

a-Mangostin has been confirmed to consist of highly biological active molecules possessing anticancer properties such as anti-proliferative, apoptotic, anti-angiogenesis and anti-metastatic effects on human cancers [8,9,24]. Krajarng et al [10] reported that $\alpha$-mangostin induced apoptotic cell death of canine OS, D-17 cells. Moreover, numerous studies indicated that inhibition of MMP expression and its activities can provide early targets for prevention of cancer metastasis $[2,4]$. Nevertheless, there has been no data reporting the effect of $\alpha-$ mangostin on the MMP-2 and MMP-9 expression in human osteosarcoma cells. To explore this effect, this study investigated the inhibitory effect of $\alpha$-mangostin on TPA-induced MMP-2 and MMP-9 at the enzymatic activities and mRNA expression. Moreover, wound healing assay was also used to determine if the a-mangostin could inhibit TPAinduced migration of U2OS cells.

The results showed that $\alpha$-mangostin inhibited MMP-9 activity stimulated by TPA in a dosedependent manner. Also, a-mangostin downregulated TPA-induced MMP-9 mRNA expression of U2OS cells. Interestingly, although a-mangostin significantly inhibited MMP-2 activity, the mRNA expression was not changed. This is possibly because a-mangostin could inhibit MMP-2 secreted from the cells (at the protein level) but it could not regulate MMP-2 expression at the transcription level

The expression of MMP-2 and MMP-9 gene is controlled by several growth factors and cytokines. By using specific inhibitors, several studies have revealed the involvement of various signaling pathways in MMP-2 and MMP-9 regulation which depends on the cell types and nature of the stimuli. Signaling pathways via
MAPKs, NF-KB, and PI3K/Akt have been reported [25]. Previous studies have reported that $\alpha$-mangostin showed antimetastatic effects in various human cancer cell lines through the different signaling pathways. For example, Lee et al [12] reported that a-mangostin suppresses TPA-induced MMP-2 and MMP-9 expression through the ERK signaling pathway in MCF-7 human breast adenocarcinoma cells.

Hung et al [11] reported that $\alpha$-mangostin exerts inhibitory effect on metastasis of PC-3 human prostate carcinoma cells by inhibiting MMP-2, MMP-9, and urokinase-plasminogen expression through the JNK signaling pathway. Moreover, Shih et al [13] demonstrated that a-mangostin suppresses phorbol 12-myristate 13-acetate (PMA)-induced MMP-2 and MMP-9 expression via avbeta3 integrin/FAK/ERK and NF-kappaB signaling pathway in A549 human lung adenocarcinoma cells. Therefore, investigation of signaling pathways and molecular mechanism associated with $\alpha$-mangostin and MMP-2 and MMP-9 expression in osteosarcoma cells should be further investigated.

Regarding the wound healing assay, the results showed that a-mangostin significantly inhibited the TPA-induced motility of U2OS cells where compared to that of TPA treatment alone. Collectively, results from gelatin zymography, real-time PCR and wound healing assay suggest that a-mangostin prevents the transcription of MMP-9 in response to TPA. Furthermore, the anti-migration effect of a-mangostin in U2OS cells was related to the inhibition of enzymatically degradative process of tumor migration. As a consequence, a-mangostin may possibly be used for suppressing tumor migration of U2OS cells at non-cytotoxic concentrations. However, metastasis of cancer cells involves multistep processes and various cyto-physiological changes. Therefore, other methods such as cellmatrix adhesion assay, invasion assay, and in vivo model need to be further explored to understand the mechanism of inhibition on osteosarcoma metastasis.

\section{CONCLUSION}

This is the first study reporting the inhibitory effects of $\alpha$-mangostin on TPA-mediated MMP-9 expression and TPA-induced migration of U2OS human osteosarcoma cells. The findings suggest that $\alpha$-mangostin has a protective effect against TPA-mediated cell migration of U2OS via the suppression of TPA-mediated MMP-9 in vitro and thus the compound is a potential therapeutic agent for the treatment of osteosarcoma. 


\section{DECLARATIONS}

\section{Acknowledgement}

This work was supported by Naresuan University (grant no. R2559C063). The authors would like to thank Professor Dr Prasit Pavasant, Faculty of Dentistry, Chulalongkorn University, for his support; Assistant Professor Dr Weeraya Tantanapornkul and Dr Jadesada Palasuk, Faculty of Dentistry, Naresuan University, for helpful discussion.

\section{Conflict of Interest}

No conflict of interest associated with this work.

\section{Contribution of Authors}

The authors declare that this work was done by the authors named in this article and all liabilities pertaining to claims relating to the content of this article will be borne by them.

\section{REFERENCES}

1. Moore DD, Luu HH. Osteosarcoma. Cancer Treat Res 2014; 162: 65-92.

2. Kessenbrock K, Plaks V, Werb Z. Matrix metalloproteinases: regulators of the tumor microenvironment. Cell 2010; 141: 52-67.

3. Wang J, Shi Q, Yuan TX, Song QL, Zhang Y, Wei Q, Zhou L, Luo J, Zuo G, Tang M, et al. Matrix metalloproteinase 9 (MMP-9) in osteosarcoma: review and meta-analysis. Clin Chim Acta 2014; 433: 225-231.

4. Roy R, Yang J, Moses MA. Matrix metalloproteinases as novel biomarkers and potential therapeutic targets in human cancer. J Clin Oncol 2009; 27: 5287-5297.

5. Korpi JT, Hagstrom J, Lehtonen N, Parkkinen J, Sorsa T, Salo $T$, Laitinen $M$. Expression of matrix metalloproteinases-2,-8,-13,-26, and tissue inhibitors of metalloproteinase-1 in human osteosarcoma. Surg Oncol 2011; 20: e18-e22.

6. Wen X, Liu H, Yu K, Liu Y. Matrix metalloproteinase 2 expression and survival of patients with osteosarcoma: a meta-analysis. Tumour Biol 2014; 35: 845-848.

7. Li H, Zhang K, Liu LH, Ouyang $Y, B u J$, Guo HB, Xiao T. A systematic review of matrix metalloproteinase 9 as a biomarker of survival in patients with osteosarcoma. Tumour Biol 2014; 35: 5487-5491.

8. Obolskiy D, Pischel I, Siriwatanametanon N, Heinrich M. Garcinia mangostana L.: a phytochemical and pharmacological review. Phytother Res 2009; 23: 10471065.

9. Jindarat S. Xanthones from mangosteen (Garcinia mangostana): multi-targeting pharmacological properties. J Med Assoc Thai 2014; 97 Suppl 2: S196201.
10. Krajarng A, Nilwarankoon $S$, Suksamrarn $S$, Watanapokasin R. Antiproliferative effect of a-mangostin on canine osteosarcoma cells. Res Vet Sci 2012; 93: 788-794.

11. Hung SH, Shen KH, Wu CH, Liu CL, Shih YW. aMangostin suppresses $P C-3$ human prostate carcinoma cell metastasis by inhibiting matrix metalloproteinase-2/9 and urokinase-plasminogen expression through the JNK signaling pathway. J Agric Food Chem 2009; 57: 1291 1298.

12. Lee YB, Ko KC, Shi MD, Liao YC, Chiang TA, Wu PF, Shih YX, Shih YW. a-Mangostin, a novel dietary xanthone, suppresses TPA-mediated MMP-2 and MMP9 expressions through the ERK signaling pathway in MCF-7 human breast adenocarcinoma cells. J Food Sci 2010; 75: H13-23.

13. Shih YW, Chien ST, Chen PS, Lee JH, Wu SH, Yin LT. $\alpha$ Mangostin suppresses phorbol 12-myristate 13-acetateinduced MMP-2/MMP-9 expressions via alphavbeta3 integrin/FAK/ERK and NF-kappaB signaling pathway in human lung adenocarcinoma A549 cells. Cell Biochem Biophys 2010; 58: 31-44.

14. Wang JJ, Sanderson BJ, Zhang W. Significant antiinvasive activities of a-mangostin from the mangosteen pericarp on two human skin cancer cell lines. Anticancer Res 2012; 32: 3805-3816.

15. Kaomongkolgit R. Alpha-mangostin suppresses MMP-2 and MMP-9 expression in head and neck squamous carcinoma cells. Odontology 2013; 101: 227-232.

16. Yuan J, Wu Y, Lu G. Alpha-mangostin suppresses lipopolysaccharide-induced invasion by inhibiting matrix metalloproteinase-2/9 and increasing E-cadherin expression through extracellular signal-regulated kinase signaling in pancreatic cancer cells. Oncol Lett 2013; 5: 1958-1964.

17. Torrungruang $K$, Vichienroj $P$, Chutimaworapan $S$. Antibacterial activity of mangosteen pericarp extract against cariogenic Streptococcus mutans. CU Dent $J$ 2007; 30: 1-10.

18. Yiemwattana I, Kaomongkolgit R. Alpha-mangostin suppresses $I L-6$ and $I L-8$ expression in $P$. gingivalis LPS-stimulated human gingival fibroblasts. Odontology 2015; 103: 348-355.

19. Latifi-Pupovci H, Kuçi Z, Wehner S, Bönig H, Lieberz R, Klingebiel $T$, Bader $P$, Kuçi $S$. In vitro migration and proliferation ("wound healing") potential of mesenchymal stromal cells generated from human CD271(+) bone marrow mononuclear cells. J Trans/ Med 2015; 13: 315.

20. Botter SM, Neri D, Fuchs B. Recent advances in osteosarcoma. Curr Opin Pharmacol 2014; 16: 15-23.

21. Letourneau PA, Xiao L, Harting MT, Lally KP, Cox CS Jr, Andrassy RJ, Hayes-Jordan AA. Location of pulmonary metastasis in pediatric osteosarcoma is predictive of outcome. J Pediatr Surg 2011; 46: 1333-1337.

22. $\mathrm{He} \mathrm{H}$, Ni J, Huang J. Molecular mechanisms of chemoresistance in osteosarcoma. Oncol Lett 2014; 7: 1352-1362.

Trop J Pharm Res, October 2016; 15(10): 2069 
23. Deryugina El, Quigley JP. Matrix metalloproteinases and tumor metastasis. Cancer Metastasis Rev 2006; 25: 934.

24. Shan T, Ma Q, Guo K, Liu J, Li W, Wang F, Wu E. Xanthones from mangosteen extracts as natural chemopreventive agents: potential anticancer drugs. Curr Mol Med 2011; 11: 666-677.

25. Mook OR, Frederiks WM, Van Noorden CJ. The role of gelatinases in colorectal cancer progression and metastasis. Biochim Biophys Acta 2004; 1705: 69-89. 